\title{
CORRESPONDENCE
}

\section{Nuclear facts}

SIR - The letter which you published on 10th July under the heading "Nuclear Protest" from three correspondents from Edinburgh Science for People, contains several misleading statements.

It is wrong to claim that trade union rights are "denied" in the nuclear power industry. Many of the staff in the industry who belong to trades union are very active in participating in debates about nuclear issues within their movement and in promoting the case for nuclear power development. They are presumably best able to judge their own conditions of employment; your correspondents should take account of their views and of those of the trade union leaders who speak for them

It is incorrect to describe the UKAEA Constabulary as "an armed secret police force"'. There is nothing secret about them. They are sworn in as special constables. They are individually responsible for their actions and their powers are more circumscribed than those of the ordinary civil police. The AEA Constabulary are responsible to the Secretary of State for Energy through the Chairman of the Authority, and their functions have been reported to and debated by Parliament.

It is impossible to claim that the civil application of nuclear energy to commercial electricity generation has led to weapons proliferation; all of the existing nuclear weapons states found ways of implementing their political decision to have such weapons which did not start from a nuclear power programme.

This exchange of letters seems to me to substantiate the need identified in your editorial (19 June) for professional people, in universities, industry and government, to resolve their points of disagreement. We should at least be able to start with a correct statement of the facts before debating the political aspects of nuclear power development.

L. E. J. RoBERTS

AERE Harwell,

OXON, UK

\section{Geological sport}

SIR - The Geological Olympics are over for another four years. The 26th International Geological Congress held on 7-17 July in Paris had the feel of an Olympic Marathon, with well over 2,500 talks in nine working days. Anybody attending each day deserved an Olympic medal for endurance, for on some days they had to make an agonizing choice between eighteen simultaneous sessions on such diverse topics as Ophiolites, Cambrian Stratigraphy, Geophysics of the Lithosphere and Upper Mantle, Applied Geochemistry, History of Tectonics pre 1922, Coal and Magnetic Stratigraphy and Ocean Floor Reconstruction.

What was the delegate likely to encounter? There was always the chance of "meeting old friends and hearing old papers" but in fact there was plenty of new research "on display". The problem was the way in which it was displayed. Having sat through approximately 2,000 slides (16 papers/day $\times$ 6.5 days $\times 20$ slides/paper $=2,080$ slides), I can honestly say that probably only one half of them were legible. The rest might well have not been shown - indeed, some speakers even apologized with the standard "If you could see the relevant points, you would notice. . .".

Why are some slides so atrocious at conferences? Admittedly some were superb large lettering, good use of colours. Others, regrettably, were just unintelligible. The slide of a table photographed directly from a journal, itself produced by offset-litho techniques is a good example. In these cases, the printing has probably been reproduced three or four times with an inevitable reduction in definition each time. The result is a blur from row 1, a sigh from the back and another author loses his audience's concentration. Maybe the time has come for "pre-talk screening" of slides to take place and rejection of those considered of dubious quality.

Apart from poor visual aids, the conference was a tremendous success. The sight of two German scientists actively discussing manganese nodules in English at a conference in France under a session chairman from Hawaii confirms that the occasion had an international flavour. But I wonder how many tribal groups (geochemists, geophysicists, petrologists, etc.) actually strayed outside their own compounds during the fortnight and how many merely "flew in" for the relevant day's papers.

Those who took this second course will have undoubtedly missed some of the more worthwhile aspects of the gathering although no doubt pressing commitments elsewhere are partly to blame for brief visits.

Maybe the Earth Scientists of today are becoming too specialized and hence, as chemists become geochemists, physicists geophysicists etc., the ability to understand broad based geology is declining.

S.J. W AKEFIELD

Dept. of Oceanography,

University College,

Swansea, UK

\section{2,4,5-T dispute}

SIR-Now that I have returned to the UK I have seen your editorial of 17 July and without complaining about the snide reference to me (no doubt prompted by your reluctance to publish the piece you requested me to write on the cancer issues) you have still got the $2,4,5-\mathrm{T}$ issue wrong. I have no idea where you got the figure of 100 tons for the quantity of herbicide-based materials imported. As far as I know it is nearer 160 tons. Nature should (as in the back part of the magazine) abandon prejudice and support quite reasonable and sane crusades to protect people.

Association of Scientific Technical Clive Jenkins and Managerial Staffs, London, UK

The source of the figures quoted in the leading article to which $\mathrm{Mr}$ Jenkins refers is as follows. Customs and Excise give imports of $2,4,5$ - $\mathrm{T}$ into the United Kingdom in 1979 as 116 tonnes. Use of the material in the United Kingdom in 1979 was given as 58 tonnes in an answer to a Parliamentary Question on 20 June. The difference is accounted for by reexports. Mr Jenkins has been informed of the source of the figures used but insists that his letter should be published. The article of his own to which Mr Jenkins refers was invited in March but not published because, in the judgement of the editorial staff of Nature, it dealt with a different aspect of the problem from that originally defined.

Editor, Nature

\section{Misciting latest}

SIR-In their News and Views article "Just so stories and cautionary tales" (Nature, 31 July) ${ }^{1}$, Robert May and Miranda Robertson quote our study ${ }^{2}$ where we point out that $W$. D. Hamilton's paper The genetical evolution of social behaviour ${ }^{3}$ is frequently miscited as The genetical theory of social behaviour. Although the recent trend to miscite the paper can be traced back to E. O. Wilson's Sociobiology, the New Synthesis ${ }^{4}$, the mutation has occurred independently at least three times and is an easy one to make for those familiar with Sir Ronald Fisher's The Genetical Theory of Natural Selection ${ }^{5}$.

Similarly, misciting Wilson's book as Sociobiology, the Modern Synthesis, as May and Robertson did, is easy to do for anyone who has read Sir Julian Huxley's Evolution, the Modern Synthesis ${ }^{6}$.

Paul Harvey JON SEGER

School of Biological Sciences University of

Sussex, Falmer, UK and Department of Biology, Harvard University, Cambridge, Massachusetts

1. Nature 286, 327-329 (1980)

2. New Scientist 87, 50-51 (1980)

3. J. theor. Biol. 7, 1-52 (1964).

4. Harvard University Press (1975).

5. Clarendon, Oxford (1930).

6. Harper, New York (1942).

\section{Distance measured}

SIR, - Bougault and Treuil in their Nature article (17 July) fail to inform us whether their distances are nautical or statute "mille passum" - there is a difference of 11.5 chains between these units, equivalent to $10,000 \mathrm{yr}$ of seafloor spreading. Confusion could be avoided, and precision improved, by quoting distances in the traditional leagues of Columbus, Champlain and the imperturbable Captain Nemo.

Department of Geology,

PAUL MOHR University College Galway, Galway, Ireland

\section{Filter tips}

SIR-Dr Zeki's red filter described in your article (Nature, 31 July, p.435) is really excellent for use in photographing fluorescent DNA bands on agarose gels. One of the most important factors for a contrast filter is the absence of fluorescence of the filter itself. Conventional red filters usually emit fairly strong fluorescence when hit by a strong UV ray from a transilluminator, and this fluorescence makes for a somewhat bright background and an unclear photograph. We have been using a UV filter in front of a conventional red filter, to cut UV light and thus to minimize the self-fluorescence of the red filter. In this manner a satisfactory photograph can be obtained. It is important to use a good UV filter, however, because some emit a weak fluorescence.

Comparison of Dr Zeki's filter with our double filter showed the former to be superior. Dr Zeki's filter is completely free of intrinsic fluorescence. My thanks to Dr Owen for his helpful observation.

TAKESHI UOZUMI Department of Agricultural Chemistry, The University of Tokyo, Japan 